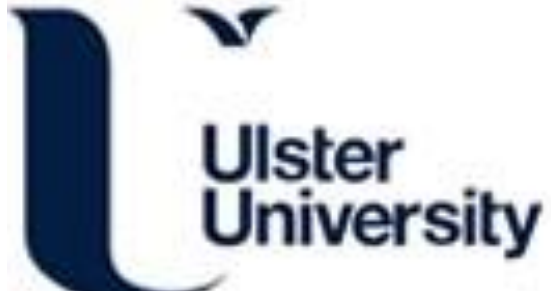

\section{Upward intergenerational influences on parents' innovativeness and innovation adoption: A comparative study of single- and multiple-child families}

\begin{abstract}
Liang, J., Jiang, H., \& Cotte, J. (2019). Upward intergenerational influences on parents' innovativeness and innovation adoption: A comparative study of single- and multiple-child families. Journal of Consumer Behaviour, 18(4), 350-359. https://doi.org/10.1002/cb.1775
\end{abstract}

Link to publication record in Ulster University Research Portal

Published in:

Journal of Consumer Behaviour

Publication Status:

Published (in print/issue): 02/07/2019

DOI:

https://doi.org/10.1002/cb.1775

\section{Document Version}

Author Accepted version

\section{General rights}

Copyright for the publications made accessible via Ulster University's Research Portal is retained by the author(s) and / or other copyright owners and it is a condition of accessing these publications that users recognise and abide by the legal requirements associated with these rights.

\section{Take down policy}

The Research Portal is Ulster University's institutional repository that provides access to Ulster's research outputs. Every effort has been made to ensure that content in the Research Portal does not infringe any person's rights, or applicable UK laws. If you discover content in the Research Portal that you believe breaches copyright or violates any law, please contact pure-support@ulster.ac.uk. 
Upward Intergenerational Influences on Parents' Innovativeness and Innovation Adoption: A Comparative Study of Single Child and Multiple Child Families

\author{
Abstract \\ In the marketing and consumer behavior literature, there has been growing \\ attention on upward intergenerational influences, or reverse socialization, which is \\ largely because of children's increasing influences on family decisions. This paper \\ hypothesizes different patterns of upward intergenerational influences in single vs. \\ multiple child families, controlling for peer and spousal influences. We found that \\ young adult single children had a direct positive influence on their parents' innovation \\ adoption behavior, but not a significant influence on their parents' overall \\ innovativeness, while young adult children with siblings had a different effect: their \\ innovativeness had a significant positive influence on their parents' overall \\ innovativeness, but not a direct impact on their parents' innovation adoption.
}

Keywords: upward intergenerational influences; innovativeness; innovation adoption; reverse socialization; family 
Upward Intergenerational Influences on Parents' Innovativeness and Innovation Adoption: A Comparative Study of Single Child and Multiple Child Families

\section{Introduction}

New product adoption and particularly, innovative consumer behavior, have been one of the most important topics for both practitioners (such as Facebook, Procter \& Gambel, Google, Apple and Tesla) and academics for decades (Goldsmith, d'Hauteville, \& Flynn, 1998; Hirschman, 1980; Midgley \& Dowling, 1978; Steenkamp \& Gielens, 2003; Steenkamp, Hofstede, \& Wedel, 1999; Venkatraman \& Price, 1990). New products and innovations are being introduced frequently to consumers, but are also highly risky ( $40 \%$ to $90 \%$ failure rate), with very costly failures for the vast majority of them in the marketplace (e.g., Webvan and Segway scooters, Gourville, 2006; and a more recent example of Google Glass), due to R\&D outcomes and marketing strategies that are not appealing to consumers (Gielens \& Steenkamp, 2007). Therefore, marketers have to understand what internal (Cotte \& Wood, 2004; Foxall \& Haskins, 1986; Hirschman, 1980; Lassar, Manolis, \& Lassar, 2005; Venkatraman \& Price, 1990; Wood \& Swait, 2002) and external factors to an 
individual (e.g., social influences, Im, Mason, \& Houston, 2007; Kulviwat, Bruner II, \& Al-Shuridah, 2009) may influence consumer adoption behavior and innovative behavior. Gatignon and Robertson (1985) developed a diffusion process model to understand the various influences on consumers who are considering adopting innovations. But very little research has investigated a unique focus on interpersonal communication transfer, one of the most important issues in diffusion research (Rogers, 2003). Similarly, although researchers have used the technology acceptance model (TAM) to understand technology adoption process for over twenty years, the role of social influence in TAM has seldom been studied (Kulviwat et al., 2009).

Social influence, as an external influence on an individual, has been considered important in innovation adoption behavior in organization research (e.g., Hausman \& Stock, 2003), but not in consumer research (Kulviwat et al., 2009) until recently (e.g., Aral, 2011; Godes, 2011; Iyengar, Bulte, \& Valente, 2011; Iyengar, Christophe, \& Valente, 2011; Narayan, Rao, \& Saunders, 2011). Researchers have found evidence of social influence on consumer innovative adoption behavior, but they tend to consider all social influences as equal (e.g., Kulviwat et al., 2009). 
At the same time, Simpson, Griskevicius, and Rothman (2012) have called for more research on the social context where consumers make decisions, and Wood and Hayes (2012) provided a review on the motives, modes, and consequences of social influence on consumer decisions to guide future research. They all examine different sources of social influences, such as romantic partners, spouses, children and friends, but it is unclear whether these social influences are equal or unequal (e.g., one social influence may dominate all the others), and how they may differ in their impacts on consumer innovation adoption when they are all considered simultaneously. Moreover, Ekström (2006) raised an interesting point about children's influence on parents: that it is still not clear whether it is due to direct learning (e.g., changes of innovativeness), or simply the behavior of keeping up with their children (e.g., adoption behavior without changes of innovativeness). These questions are critical: theoretically, these influences may not have equal effects on the target (e.g., one influence may have a dominant effect), and they may have different underlying mechanisms and boundary conditions. Practically, if marketers think that all social influences are equal, they may waste time and resources in their influence strategies that may not provide any 
positive outcomes.

In this paper, we make several important theoretical and practical contributions to the literature. First, we examine upward intergenerational influences in the new product adoption area by comparing and controlling the influences of the target parent's spouses (inside family) and friends (outside family), that have been largely neglected in the children's influence literature. Second, we demonstrate the boundary conditions of upward intergenerational influences, and explain the underlying mechanisms between single-child and multiple-child families, especially on the target parent's innovativeness and actual innovation adoption behavior. Finally, this research provides insightful implications for practitioners, to better target their influence strategies at single-child and multiple-child families, especially when they want to increase the new product adoption possibilities for parents (who may be slow- or non-adopters by themselves, as age is negatively correlated with consumer innovativeness and innovation adoption, Gielens \& Steenkamp, 2007; Hirunyawipada \& Paswan, 2006; Im et al., 2003, 2007; Steenkamp et al., 1999). 


\section{Upward Intergenerational Influences}

Children have an important influence on parents during social interactions; there is a long stream of research in sociology (Brim, 1968), anthropology (Mead, 1970), and consumer research (Grossbart, Hughes, Pryor, \& Yost, 2002; Sorce, Loomis, \& Tyler, 1989; Ward, 1974; Watne, Lobo, \& Brennan, 2011) that demonstrates that children may influence their parents' attitudes and behaviors, often referred to as "reverse socialization," although we prefer the term upward intergenerational influences (Grossbart et al., 2002).

Family, as a fundamental unit in society, has received limited attention in the consumer adoption and innovation diffusion literature, with a few exceptions (e.g., Cotte \& Wood, 2004). Parents with young adult children are likely major target consumers for many companies and firms. In many countries, young adult children remain living at home longer than they did in the past, and so the parents' decisions in consumption domains could be influenced by these close adult children (Sorce et al., 1989), in addition to traditionally studied sources of influence, such as young children, spouses, and friends (Baranowski, 1978; Brim, 1968; Papert, 1996; Peters, 1985; 
Tapscott, 1998).

Interestingly, in the innovation domain, although young adult children may influence their parents' decision making, such upward intergenerational influences have seldom been investigated (but see Mathur, 1999). Thus, it is unclear whether young adult children could influence their parents' innovation adoption, and how significant this upward intergenerational influences are, compared to spousal and peer influences.

Spousal influence on joint family decision making has been found in many studies (Su, Zhou, Zhou, \& Li, 2008), such as spousal influence strategies to resolve conflict between preferences (Webster \& Reiss, 2001) and spousal behavioral interactions across decision episodes to reach harmony (Corfman \& Lehmann, 1993). Peer influences from friends, due to selection and socialization effects, have also been found in various areas, including antisocial, deviant and health-risk behaviors (Brechwald \& Prinstein, 2011). Peer socialization may occur through modeling or imitation, as well as through social comparison or behavioral approximation (Brechwald \& Prinstein, 2011). But in addition to these spousal and peer socialization 
effects, there have been calls for more research into what types of attitudes and behaviors that parents actually learn from their children (Ekström, 2006, 2007;

Moschis, 1987). Watne, Lobo and Brennan (2011) found that in the technology space, children are seen to have expert power, and to influence their parents' behaviors (see also Mathur 1999). Furthermore, Ekström (2006) argued that while it is not clear whether it is because of direct learning, or because parents want to keep up with their children, it is clear that children influence their parents in terms of diffusion of innovations.

This research examines these different types of social influences on consumer innovation adoption. In a novel way, we investigate the influences of young adult children, while simultaneously controlling for spousal and peer influences, on the target parent's innovativeness and innovation adoption, and we compare the different patterns between single child and multiple child families. The setting for our research is China, the only country that has enforced a one-child policy for more than 30 years (especially in cities and urban areas). China is an interesting setting to test our ideas, particularly as other researchers have found differences in family decision-making in 
China, as compared to the U.S. (Wang, Holloway, Beatty, \& Hill, 2007). Also,

Chinese children and adolescents do show evidence of upward intergenerational influences (McNeal \& Yeh, 2003; Wang et al., 2007).

\section{Innovativeness}

Consumer innovativeness is defined as individuals' underlying preference for new and different experience (Hirschman, 1980; Venkatraman \& Price, 1990), or the tendency to willingly embrace change and try new things (Cotte \& Wood, 2004). Like these seminal works, our approach to consumer innovativeness is multidimensional;

we believe consumer innovativeness includes both cognitive (propensity to engage in experiences that stimulate thinking) and sensory (actively seeking stimulation and arousal from novelty) aspects. As such, we continue in a long tradition of considering consumer innovativeness to be a multidimensional construct (Cotte \& Wood, 2004; Hirschman, 1980; Hirunyawipada \& Paswan, 2006; Park, Yu, \& Zhou, 2010; Venkatraman \& MacInnis, 1985; Venkatraman \& Price, 1990; Wood \& Swait, 2002). Following Wood and Swait (2002) and Cotte and Wood (2004), we will measure consumer innovativeness as two subscales, reflecting these cognitive and sensory 
components.

A substantial body of research has already demonstrated the association between consumer innovativeness and innovative behavior or adoption (Goldsmith, Freiden, \& Eastman, 1995; Im, Bayus, \& Mason, 2003; Manning, Bearden, \& Madden, 1995). For example, Lu, Yao and Yu (2005) found that individuals with higher personal innovativeness in information technology are likely to have more positive intentions to adopt high technology. Although some studies have been equivocal on the relationship between consumer innovativeness and innovative adoption behavior (for recent reviews, see Bartels \& Reinders, 2011 and Kaushik \& Rahman, 2014), we maintain that consumer innovativeness is an important indicator of consumers' actual preferences for new products, and might have an impact on their innovation adoption (see Cotte \& Wood, 2004; Wood \& Swaite, 2002).

Considering what can influence consumer innovativeness and consumer innovation adoption or behavior, we turn to family, as one source of social influence (Cotte \& Wood, 2004). Social influences, such as upward intergenerational influences, can impact consumers' innovation adoption behavior directly (i.e. without changing 
someone's underlying innovativeness) and indirectly (i.e. by changing someone's

underlying innovativeness). Several researchers have demonstrated that social

influence is a critical element in consumers' adoption intention for innovations (Kim

\& Park, 2011; Kulviwat et al., 2009). According to Social Learning Theory (SLT;

Bandura, 1977), human cognition and behavior are learned observationally within a

social context through continuous social interactions. Thus, social influence may be

particularly important for parents' innovation adoption decisions, which requires

gathering a large body of information from different people in society, including

watching what their own adult children do.

\section{Upward Intergenerational Influences on Innovativeness}

Researchers have demonstrated that children impact their parents' purchasing

decisions (Baldassarre, Campo, \& Falcone, 2016; Nicholls \& Cullen, 2004; Wilson \&

Wood, 2004), and the values or attitude of their parents (Dillon, 2002). If children

have more knowledge of a product, they could exert more influence on parents'

purchase decision for that product (Thomson, Laing, \& McKlee, 2007). And age has

been shown to be negatively correlated with consumer innovativeness (Gielens \& 
Steenkamp, 2007; Hirunyawipada \& Paswan, 2006; Im et al., 2003, 2007; Steenkamp et al., 1999). Therefore, compared with parents, young adult children are likely to be more knowledgeable about innovative products, and more likely to be the early adopters of innovations in a family. Consequently, young adult children could have a significant impact on parents' innovativeness and the adoption of innovative products. Compared to parents of multiple children, parents with a single child tend to devote greater attention to this only child, and are more inclined to cater to their child's needs for products (Falbo, 1987). Thus, in a single child family, the influence of the child on their parents' purchases is usually through pestering behavior. As a result, although single children in a family may have direct influence on parents' innovation adoption, parents' freedom of choice and independence could feel threatened. Psychological Reactance Theory (Clee \& Wicklund, 1980) states that when people's freedom is threatened, they will react against attempts to control their behavior. Moreover, when social influence attempts are the source of reactance, people are more likely to move in the direction opposite from the influence effort. In light of this, we posit that young adult single children would exert no significant 
impact on parents' innovativeness, due to parents' reactance to their influence. In contrast, parents are less likely to be able to cater to multiple children's needs, thus they will not tend to react against their child's influence, and their innovativeness is more likely to be influenced. Therefore, we posit that while a young adult single child exerts no direct significant influence on parents' innovativeness (due to reactance), young adults in a multiple sibling family will significantly influence their parents' innovativeness (due to social and direct learning).

In addition, consumers' peers can have a positive influence on behavior by encouraging positive behavior, such as academic success or healthy lifestyles (Costello \& Hope, 2016). For instance, prior research has shown a relationship between people's assessments of their peers' volunteering behaviors and their own self-reported volunteering behaviors (Law, Shek, \& Ma, 2013). Peer socialization may involve the adoption of peers' valued behaviors or treasured products. Peer influence is one of the most powerful predictors of risk behavior (Jaccard, Blanton, \& Dodge, 2005), and health-risk behaviors (Prinstein \& Dodge, 2008).

Besides, spousal preference usually exerts another significant influence in family 
decision making (Beharry-Borg, Hensher, \& Scarpa, 2009; Carlsson, He, Martinsson,

Qin, \& Sutter, 2012). When a family purchase results in conflict, spouses' influence

tactics play important roles (Kirchler, 1990). Spouses influence each other in purchase

decisions. Overall, peers and spouses may exhibit great influences on parents'

innovativeness and innovation adoption. Therefore, we attempt to control for the

influences of peer and spouse when investigating the upward intergenerational

influences. Based on the literature, we posit that parents' innovation adoption is

directly (vs. indirectly) influenced by the innovativeness of young adult children in

single child (vs. multiple child) families. The upward intergenerational influences on

the parent from an adult child hold even when controlling for the influences from peer

and spouse. More specifically, our hypotheses are:

H1a: The innovativeness of young adult children in single-child families has a

positive direct influence on parents' actual innovation adoption behavior.

H1b: The innovativeness of young adult children in multiple-child families has a

positive indirect influence on parents' actual innovation adoption behavior via

parents' innovativeness. 


\section{Method}

\section{Participants}

We recruited participants from undergraduate students, their families, and their parents' friends in various cities across China. Initially, we recruited undergraduate students and asked them to distribute the other questionnaires to both their parents (to measure and control for spousal influence) and one of their parents' friends (to measure and control for peer influence). They were paid RMB 50 Yuan (about US\$8.5) when they returned the whole package, regardless of whether all questionnaires were filled out. A total of 300 packages were distributed, and 240 sets of questionnaires were returned.

\section{Measures}

As outlined in our literature review, there is a solid tradition of measuring consumer innovativeness as a multidimensional construct involving both cognitive and sensory aspects (e.g. Venkatraman \& Price, 1990). Following recent tradition (see Wood \& Swaite, 2002, and Cotte \& Wood, 2004), we measured Need for Cognition (five-item) and Need for Change (six-item) as two innovativeness indicators for each 
participant (see appendix). Child innovativeness (CI), spouse innovativeness (SI) and peer innovativeness (PI) were provided as the index of child influence, spouse influence and peer influence separately. Moreover, adapted from Cotte and Wood (2004), we measured innovation adoption using the ownership of a number of products and services, which were pretested (we interviewed parents in different Chinese families and consulted with professors and experts in new products and innovation areas) to be considered innovative for parents at the time of the data collection, including online shopping, skin-care products, digital video cameras, micro-blog, online communication tools, health-care products, etc. As in Cotte \& Wood (2004), we summed the innovative products/services adoption behavior for each product and service ( $1=$ adoption, $0=$ non-adoption) to create an Index of Innovation Adoption. Demographics (e.g., age, gender, number of siblings, birth order, education and income) were measured at the end of the questionnaire.

\section{Results}

A structural equation model (SEM) was used to test how the innovative adoption of the target parent (the parent who asked a friend to participate in this study) was 
affected by the relative influences of their adult children (the undergraduate students), spouses (the students' other parent), and peers (the parents' friends who participated in this study). In the conceptual model (see Figure 1), the constructs of innovativeness of adult children, spouses, and peers were used as the independent variables, and the target's innovativeness was used as the mediator, followed by the target's innovative adoption as the dependent variable. In the measurement model (see Table 1), the constructs of innovativeness of adult children, spouses, and peers included measures of Need for Cognition $(\alpha=.71)$, Need for Change $(\alpha=.62)$, and innovation adoption. The target's innovativeness included measures of Need for Cognition and Need for Change. The target's innovative adoption was measured by an index of innovative products and services. Social economic status (SES) was a control variable measured as a formative construct including the target parent's age, education, and income. 
Using innovation adoption as the dependent variable, our structural model

possessed very good fit indices: a likelihood ratio statistic less than $3\left(\chi^{2} / \mathrm{df}=1.33\right)$,

GFI of .97, RMSEA of .03 (Bagozzi \& Yi, 2012). Moreover, NFI was .91, IFI was .98,

CFI was .97, TLI was .94, and RMR was .04, which all met the standard criteria in

SEM (Hu \& Bentler, 1999).

Using the whole sample (see Table 1), we found an upward intergenerational

influence $(\beta=.18, p<.01)$ on the target's innovativeness (TI), even controlling for peer influence $(\beta=.34, p<.001)$ and spousal influence $(\beta=.26, p<.001)$ in the model using the target's innovation adoption (TIA) as dependent variable. We used the results in the full mediation model to illustrate the effects of different social influences (results remain the same in all three models).

Insert Table 1 about here

Furthermore, we found that in the structural model for single child families $(n=135)$ (see Table 2), the partial mediation model was better than the full mediation 
model using innovation adoption as the dependent variable $\left(\triangle \chi^{2}{ }_{(3)}=10.82, p<.05\right)$.

Moreover, young adult children from one child families had a strong (the strongest

among all influencers in the model) and positive direct influence on a target's

innovation adoption $(\beta=.82, p<.01)$ without the mediation effects of the target's

innovativeness. Hence, H1a was supported.

Insert Table 2 about here

However, in the structural model for multiple child families $(n=204$, see Table 3$)$,

the partial mediation model was not better than the full mediation model using the

innovation adoption as dependent variable $\left(\triangle \chi^{2}{ }_{(3)}=6.32, p>.05\right)$, and all direct

influence paths to parent innovation adoption were non-significant, including the one

from young adult children $(\beta=-.16, p=\mathrm{ns})$. Hence, $\mathrm{H} 1 \mathrm{~b}$ was supported.

Insert Table 3 about here 


\section{Discussion}

This research makes several theoretical contributions. First, the results of this

study enrich the innovation adoption literature by introducing upward

intergenerational influences, while comparing and controlling the influences inside

families (i.e., the target parents' spouses) and outside families (friends of the target

parents). Previous research has mainly focused on the intergenerational influences

from parents to children (e.g., O'Connor, 1979; Peterson \& Mccabe, 2004) or on the

influences of adolescents (under the age of 18) on parents (e.g., Dalakas \& Shoham,

2006; Jenkins, 1979). This paper is one of the first attempts to investigate the upward

intergenerational influences of young adult children (above the age of 18) on parents

in the innovation diffusion context. Furthermore, the roles of peers and spouses'

impact has not been considered into prior study of upward intergenerational

influences. In this research, we simultaneously control for the influences of family

members (spouses) and influences outside families (peers).

Second, based on a new perspective of Psychological Reactance Theory, we

identify the moderation effects of single- and multiple-child families on upward 
intergenerational influences and provide an explanation for their different underlying mechanisms. This research has demonstrated that adult children from single child families and multiple sibling families have different patterns of influence on their parents. We are the first to provide insights into the studies of single child vs. multiple child influences on parents' consumption behavior. In past research, the child' influences on parents' consumption behavior was considered simply, and the differences between single and multiple child families were ignored (Dalakas \& Shoham, 2006; Jenkins, 1979). In contrast to those previous studies, our findings indicate that a young adult from a single child family has a direct positive influence on his or her parents' innovation adoption behavior, but not a significant influence on his or her parents' trait innovativeness. However, for young adults from multiple child families, their own innovativeness has a significant positive influence on their parents' innovativeness, but not a direct impact on parents' adoption of innovative products.

These results could be explained by the Psychological Reactance Theory (Clee \& Wicklund, 1980). Specifically, parents are more likely to react against their children's influence by not changing their own innovativeness in single child families, compared 
with multiple-child families. These results help answer the question about children's influence on parents raised by Ekström (2006): that it is still not clear whether it is due to direct learning (e.g., changes of innovativeness), or simply the behavior of keeping up with their children (e.g., adoption behavior without changes of innovativeness). However, these differing effects of multiple siblings versus single children on upward intergenerational influences deserve more research, specifically across a wide variety of purchase and consumption contexts.

This study also provides practical implications for marketers. First, given that parents' innovative adoption is influenced by adult children, marketers' efforts toward parents could also focus on their offspring. Marketers could use appeals to encourage adult children to diffuse innovative products to their parents, who are usually slow- or non-adopters of those innovation by themselves. For example, marketers could promote gift-giving (i.e., more direct ways) and/or WOM (i.e., more indirect ways) of new products from young adult children to parents.

However, their marketing strategies should be different for single- and multiple-child families. Specifically, for single child families, children's influence on 
parents' actual innovation adoption behavior should be encouraged (e.g., more direct ways of gift-giving), while for multiple child families, children's influence on parents' actual innovation adoption behavior seems to be more indirect via parents' innovativeness traits (e.g., more indirect ways of WOM). Nevertheless, this influence may be more significant in the long run, as parents' innovativeness could be an important predictor for the innovation adoption behaviors in which parents are really interested (e.g., leading to more adoptions of other relevant or even irrelevant new products and innovations), instead of a compliance with children's preferences (e.g., leading to the adoptions of only those new products and innovations given directly by the children). Marketers could use the children's innovativeness in multiple child families to predict how innovative their parents could be, and how likely their parents could adopt innovations beyond children's preferences, but within parents' interests, especially when it is more difficult or more costly to measure the parents' innovativeness than their children's innovativeness. For example, marketers can target both young adult children and their parents for new product adoptions in the same multiple-child families by simply measuring the young adult children's 
innovativeness instead of measuring both children and parents' innovativeness (which is more difficult and most costly).

Despite these strengths, this study also has several limitations. One way to improve on this kind of research is using a longitudinal design to examine the causal relationship between children's innovativeness and parents' innovative adoption. Second, future research should probe into other motivational variables for the present conceptual framework, such as uniqueness-seeking and sensation-seeking (Burns \& Krampf, 1992). The addition of other essential linkages would provide for a more thorough underlying mechanism accounting for the parents' innovation adoption. In addition, the participants in this study are all from a single country that represents a collectivistic culture. The data should be collected from multiple countries to confirm the conclusion about upward intergenerational influences across different cultures in the future studies. 
UPWARD INTERGENERATIONAL INFLUENCES AND INNOVATION ADOPTION

\section{References}

Aral, S. (2011). Identifying social influence: A comment on opinion leadership and social contagion in new product diffusion. Marketing Science, 30(2), 217-223. https://doi.org/10.1287/mksc.1100.0596

Bagozzi, R. P., \& Yi, Y. (2012). Specification, evaluation, and interpretation of structural equation models. Journal of the Academy of Marketing Science, 40(1), 8-34. https://doi.org/10.1007/s11747-011-0278-x

Baldassarre, F., Campo, R., \& Falcone, A. (2016). Food for kids: How children influence their parents purchasing decisions. Journal of Food Products Marketing, 22(5), 596-609. https://doi.org/10.1080/10454446.2016.1141143

Bandura, A. (1977). Social learning theory. Englewood Cliffs, NJ: Prentice-Hall.

Baranowski, M. D. (1978). Adolescents' attempted influence on parental behaviors. Adolescence, 13(52), 585-604.

Beharry-Borg, N., Hensher, D. A., \& Scarpa, R. (2009). An analytical framework for joint vs separate decisions by couples in choice experiments: The case of coastal water quality in Tobago. Environmental \& Resources Economics, 43(1), 95-117. https://doi.org/10.1007/s10640-009-9283-7 
Brechwald, W. A., \& Prinstein, M. J. (2011). Beyond homophily: A decade of advances in understanding peer influence process. Journal of Research on Adolescence, 21 (1), 166-179. https://doi.org/10.1111/j.1532-7795.2010.00721.x

Bartels, J., \& Reinders, M. J . (2011). Consumer innovativeness and its correlates: A propositional inventory for future research. Journal of Business Research, 64(6), 601-609. https://doi.org/10.1016/j.jbusres.2010.05.002

Brim, O. G. Jr. (1968). Adult socialization. In J. A. Clausen (Ed.), Socialization and society (pp. 182-226). Boston: Little, Brown.

Burns, D. J., \& Krampf, R. F. (1992). Explaining innovative behaviour: uniqueness-seeking and sensation-seeking. International Journal of Advertising, 11(3), 227-237. https://doi.org/10.1080/02650487.1992.11104497

Carlsson, F., He, H., Martinsson, P., Qin, P., \& Sutter, M. (2012). Household decision making in rural China: Using experiments to estimate the influences of spouses. Journal of Economic Behavior \& Organization, 84(2), 525-536. https://doi.org/10.1016/j.jebo.2012.08.010

Clee, M. A., \& Wicklund, R. A. (1980). Consumer behavior and psychological 
UPWARD INTERGENERATIONAL INFLUENCES AND INNOVATION ADOPTION

reactance. Journal of Consumer Research, 6(4), 389-405.

https://doi.org/10.1086/208782

Corfman, K. P., \& Lehmman, D. R. (1993). The importance of others' welfare in evaluating bargaining outcomes. Journal of Consumer Research, 20(1), 124-137. https://doi.org/10.1086/209338

Costello, B. J., \& Hope, T. L. (2016). Peer pressure, peer prevention: The role of friends in crime and conformity. New York: Routledge.

Cotte, J., \& Wood, S. L. (2004). Families and innovative consumer behavior: A triadic analysis of sibling and parental influence. Journal of Consumer Research, 31(1), 78-86. https://doi.org/10.1086/383425

Dalakas, V., \& Shoham, A. (2006). How our adolescent children influence us as parents to yield to their purchase requests. Journal of Consumer Marketing, 23(6), 344-350. https://doi.org/10.1108/07363760610701887

Dillon, J. J. (2002). The role of the child in adult development. Journal of Adult Development, 9(4), 267-275. https://doi.org/10.1023/A:1020286910678

Ekström, K. M. (2006). Consumer socialization revisited. Research in Consumer 
UPWARD INTERGENERATIONAL INFLUENCES AND INNOVATION ADOPTION

Behavior, 10, 71-98. https://doi.org/10.1016/S0885-2111(06)10004-6

Ekström, K. M. (2007). Parental consumer learning or keeping up with the children.

Journal of Consumer Behavior, 6(4), 203-217. https://doi.org/10.1002/cb.215

Falbo, T. (1987). Only children in the United States and China. Applied Social

Psychology Annual, 7, 159-183.

Foxall, G., \& Haskins, G. G. (1986). Cognitive style and consumer innovativeness.

European Journal of Marketing, 20(3/4), 63-80.

https://doi.org/10.1108/EUM0000000004755

Gatignon, H., \& Robertson T. S. (1985). A propositional inventory for new diffusion

research. Journal of Consumer Research, 11(4), 849-867.

https://doi.org/10.1086/209021

Gielens, K., \& Steenkamp, J. B. E. M. (2007). Drivers of consumer acceptance of new

packaged goods: An investigation across products and countries. International

Journal of Research in Marketing, 24(2), 97-111.

http://doi.org/10.1016/j.ijresmar.2006.12.003

Godes, D. (2011). Invited comment on "opinion leadership and social contagion in 
new product diffusion”. Marketing Science, 30(2), 224-229.

https://doi.org/10.1287/mksc.1100.0605

Goldsmith, R. E., d'Hauteville, F., \& Flynn, L. R. (1998). Theory and measurement on consumer innovativeness. European Journal of Marketing, 32(3/4), 340-353. http://doi.org/10.1108/03090569810204634

Goldsmith, R. E., Freiden, J. B., \& Eastman, J. K. (1995). The generality/specificity issue in consumer innovativeness research. Technovation, 15(10), 601-611. https://doi.org/10.1016/0166-4972(95)99328-D

Gourville, J. T . (2006). Eager sellers and stony buyers: Understanding the psychology of new-product adoption. Harvard Business Review, 84(6), 98-106.

Grossbart, S., Hughes, S. M., Pryor, S., \& Yost, A. (2002). Socialization aspects of parents, children, and the internet. In S. M. Broniarczyk, \& K. Nakamoto (Eds), Advances in consumer research (Vol. 29, pp. 66-70). Provo, UT: Association for Consumer Research.

Hausman, A., \& Stock, J. R. (2003). Adoption and implementation of technological innovations within long-term relationships. Journal of Business Research, 56(8), 
UPWARD INTERGENERATIONAL INFLUENCES AND INNOVATION ADOPTION

681-686. https://doi.org/10.1016/S0148-2963(01)00313-7

Hirschman, E. C. (1980). Innovativeness, novelty seeking, and consumer creativity.

Journal of Consumer Research, 7(3), 283-295. https://doi.org/10.1086/208816

Hirunyawipada, T., \& Paswan, A. K. (2006). Consumer innovativeness and perceived risk: Implications for high technology product adoption. Journal of Consumer Marketing, 23(4), 182-198. http://doi.org/10.1108/07363760610674310

Hu, L., \& Bentler, P. M. (1999). Cutoff criteria for fit indexes in covariance structure analysis: Conventional criteria versus new alternatives. Structural Equation Modeling, 6 (1), 1-55. https://doi.org/10.1080/10705519909540118

Im, S., Bayus, B. L., \& Mason, C. H. (2003). An empirical study of innate consumer innovativeness, personal characteristics, and new-product adoption behavior. Journal of the Academy of Marketing Science, 31(1), 61-73. https://doi.org/10.1177/0092070302238602

Im, S., Mason, C. H., \& Houston, M. B. (2007). Does innate consumer innovativeness relate to new product service adoption behavior? The intervening role of social learning via vicarious innovativeness. Journal of the Academy of Marketing 
Science, 35(1), 63-75. https://doi.org/10.1007/s11747-006-0007-z

Iyengar, R., Bulte, C. V. D., \& Valente, T. W. (2011), Opinion leadership and social contagion in new product diffusion. Informs, 30(2), 224-229.

https://doi.org/10.1287/mksc. 1100.0566

Iyengar, R., Christophe, V. D. B., \& Valente, T. W. (2011). Rejoinder-further reflections on studying social influence in new product diffusion. Marketing Science, 30(2), 230-232. https://doi.org/10.1287/mksc.1100.0614 Jaccard, J., Blanton, H., \& Dodge, T. (2005). Peer influences on risk behavior: An analysis of the effects of a close friend. Developmental Psychology, 41(1), 135-147. https://doi.org/10.1037/0012-1649.41.1.135

Jenkins, R. L. (1979). The influence of children in family decision making: Parents' perceptions. Advances in Consumer Research, 6(1), 413-418.

Kaushik, A. K., \& Rahman, Z. (2014). Perspectives and dimensions of consumer innovativeness: A literature review and future agenda. Journal of International Consumer Marketing, 26(3), 239-263. http://doi.org/10.1080/08961530.2014.893150 
Kim, S. H., \& Park, H. J. (2011). Effects of social influence on consumers' voluntary adoption of innovations prompted by others. Journal of Business Research, 64(11), 1190-1194. https://doi.org/10.1016/j.jbusres.2011.06.021

Kirchler, E. (1990). Spouses' influence strategies in purchase decisions as dependent on conflict type and relationship characteristics. Journal of Economic Psychology, 11(1), 101-118. https://doi.org/10.1016/0167-4870(90)90049-F

Kulviwat, S., Bruner II, G. C., \& Al-Shuridah, O. (2009). The role of social influence on adoption of high tech innovations: The moderating effect of public/private consumption. Journal of Business Research, 62(7), 706-712. https://doi.org/10.1016/j.jbusres.2007.04.014

Lassar, W. M., Manolis, C., \& Lassar, S. S. (2005). The relationship between consumer innovativess, personal characteristics, and online banking adoption. International Journal of Bank Marketing, 23(2), 176-199. https://doi.org/10.1108/02652320510584403

Law, B. M. F., Shek, D. T. L., \& Ma, C. M. S. (2013). Validation of family, school, and peer influence on volunteerism scale among adolescents. Research on Social 
UPWARD INTERGENERATIONAL INFLUENCES AND INNOVATION ADOPTION

Work Practice, 23(4), 458-466. https://doi.org/10.1177/1049731513476144

Lu, J., Yao, J. E., \& Yu, C. S. (2005). Personal innovativeness, social influences and adoption of wireless Internet services via mobile technology. Journal of Strategic Information Systems, 14(3), 245-268. https://doi.org/10.1016/j.jsis.2005.07.003

Manning, K. C., Bearden, W. O., \& Madden, T. J. (1995). Consumer innovativeness and adoption process. Journal of Consumer Psychology, 4(4), 329-345. https://doi.org/10.1207/s15327663jcp0404_02

Mathur, A. (1999). Adoption of technological innovations by the elderly: A consumer socialization perspective. Journal of Marketing Management, 9(3), 21-35.

McNeal, J. U., \& Yeh, C.H. (2003). Consumer behavior of Chinese children: 1995-2002. Journal of Consumer Marketing, 20(6), 542-554. https://doi.org/10.1108/07363760310499129

Mead, M. (1970). Culture and commitment: A study of the generation gap. New York: Natural History Press/Doubleday and Co. Inc.

Midgley, D. F., \& Dowling, G. R. (1978). Innovativess: The concept and its measurement. Journal of Consumer Research, 4(4), 229-242. 
UPWARD INTERGENERATIONAL INFLUENCES AND INNOVATION ADOPTION

https://doi.org/10.1086/208701

Moschis, G. P. (1987). Consumer socialization: A life-cycle perspective. Lexington,

MA: Lexington Books.

Narayan, V., Rao, V. R., \& Saunders, C. (2011). How peer influence affects attribute preferences: A bayesian updating mechanism. Marketing Science, 30(2), 368-384. https://doi.org/10.1287/mksc.1100.0618

Nicholls, A. J., Cullen, B. (2004). The child-parent purchase relationship: Pester power, human rights and retail ethics. Journal of Retailing \& Consumer Services, 11(2), 75-86. https://doi.org/10.1016/S0969-6989(02)00080-2

O'Connor, J. (1979). The transmission of drinking behaviour from parents to children: Influences in the development of drinking behaviour. Journal of Comparative Family Studies, 10(2), 253-270.

Papert, S. (1996). The connected family: Bridging the digital generation gap. Atlanta: Longstreet Press.

Park, J. E., Yu, J., \& Zhou, J. X. (2010). Consumer innovativeness and shopping styles. Journal of Consumer Marketing, 27(5), 437-446. 
UPWARD INTERGENERATIONAL INFLUENCES AND INNOVATION ADOPTION

https://doi.org/10.1108/07363761011063330

Peters, J. F. (1985). Adolescents as socialization agents to parents. Adolescence,

20(80), 921-933. https://doi.org/10.1016/0306-4603(85)90044-9

Peterson, C., \& Mccabe, A. (2004). Echoing our parents: parental influences on

children's narration. In M. W. Pratt, \& B. E. Fiese (Eds.), Family stories and the life course: Across time and generations (pp. 27-54). Mahwah, NJ: Erlbaum.

Prinstein, M. J., \& Dodge, K. A. (2008). Understanding peer influence in children and adolescents. New York, NY: Guilford Press.

Rogers, E. M. (2003). Diffusion of innovations. New York: Free Press.

Simpson J. A., Griskevicius V., \& Rothman, A. J. (2012). Bringing relationships into consumer decision-making. Journal of Consumer Psychology, 22(3), 304-314. https://doi.org/10.1016/j.jcps.2012.05.004

Sorce, P., Loomis L., \& Tyler, P. R. (1989). Intergenerational influences on consumer decision making. In T. K. Srull (Ed.), Advances in consumer research (Vol.16, pp. 271-275). Provo, UT: Association for Consumer Research.

Steenkamp, J. B. E. M., \& Gielens, K. (2003). Consumer and market drivers of the 
trial probability new consumer packaged goods. Journal of Consumer Research, 30(3), 368-384. https://doi.org/10.1086/378615

Steenkamp, J.-B. E. M., Hofstede F. t., \& Wedel, M. (1999). A cross-national investigation into the individual and national cultural antecedents of consumer innovativeness. Journal of Marketing, 63(2), 55-69

https://doi.org/10.2307/1251945

Su, C., Zhou, K. Z., Zhou, N., \& Li, J. J. (2008). Harmonizing conflict in husband-wife purchase decision making: Perceived fairness and spousal influence dynamics. Journal of the Academy of Marketing Science, 36(3), 378-394. https://doi.org/10.1007/s11747-007-0079-4

Tapscott, D. (1998), Growing up digital: The rise of the net generation. New York: McGraw Hill.

Thomson, E. S., Laing, A. W., \& McKlee, L. (2007). Family purchase decision making: Exploring child influence behavior. Journal of Consumer Behavior, 6(4), 182-202. https://doi.org/10.1002/cb.220

Venkatraman, M. P., \& Price, L. L. (1990). Differentiating between cognitive and 
sensory innovativeness: Concepts, measurement, and implications. Journal of

Business Research, 20(4), 293-315.

https://doi.org/10.1016/0148-2963(90)90008-2

Venkatraman, M. P., \& MacInnis, D. J. (1985). An investigation of the epistemic and sensory exploratory behaviors of hedonic and cognitive consumers. In E. C. Hirschman, \& M. L. Holhrook (Eds.), Advances in consumer research (Vol.12, pp. 102-107). Provo, UT: Association for Consumer Research.

Wang, S., Holloway, B. B., Beatty, S. E., \& Hill, W. W. (2007). Adolescent influence in family purchase decisions: An update and cross-national extension. Journal of Business Research, 60(11), 1117-1124.

https://doi.org/10.1016/j.jbusres.2007.04.004

Ward, S. (1974). Consumer socialization. Journal of Consumer Research, 1(2), 1-14. https://doi.org/10.1086/208584

Watne, T., Lobo, A., \& Brennan, L. (2011). Children as agents of secondary socialization for their parents. Young Consumers, 12(4), 285-294. https://doi.org/info:doi/10.1108/17473611111185841 
Webster, C., \& Reiss, M. C. (2001). Do established antecedents of purchase decision-making power apply in contemporary couples? Psychology \& Marketing, 18(9), 951-961. https://doi.org/10.1002/mar.1037

Wilson, G., \& Wood, K. (2004). The influence of children on parental purchases during supermarket shopping. International Journal of Consumer Studies, 28(4), 329-336. https://doi.org/10.1111/j.1470-6431.2004.00393.x

Wood S., \& Swait, J. (2002). Psychological indicators of innovation adoption:

Cross-classification based on need for cognition and need for change. Journal of Consumer Psychology, 12(1), 1-13.

http://doi.org/10.1207/S15327663JCP1201_01

Wood, W., \& Hayes, T. (2012). Social influence on consumer decisions: Motives, modes, and consequences. Journal of Consumer Psychology, 22(3), 324-328. https://doi.org/10.1016/j.jcps.2012.05.003 


\section{APPENDIX}

\section{Measurement scales}

\begin{tabular}{|c|c|}
\hline $\begin{array}{l}\text { Need for Cognition (Adapted from Cotte } \\
\text { and Wood 2004) }\end{array}$ & $\begin{array}{l}\text { a) I would rather do something that } \\
\text { requires little thought than something that } \\
\text { is sure to challenge my thinking abilities. }\end{array}$ \\
\hline \multirow{4}{*}{$\begin{array}{l}\text { (5-point scale, } 1=\text { disagree completely, } \\
5=\text { agree completely) } \\
\text { (Average Cronbach's alpha for self-ratings } \\
\text { is }=.71 \text {; Average Cronbach's alpha for } \\
\text { rating others is }=.71 \text { ) }\end{array}$} & $\begin{array}{l}\text { b) I try to anticipate and avoid situations } \\
\text { where there is a likely chance I'll have to } \\
\text { think in depth about something. }\end{array}$ \\
\hline & c) I only think as hard as I have to. \\
\hline & $\begin{array}{l}\text { d) The idea of relying on thought to get } \\
\text { my way to the top does not appeal to me. }\end{array}$ \\
\hline & $\begin{array}{l}\text { e) The notion of thinking abstractly is not } \\
\text { appealing to me. }\end{array}$ \\
\hline \multirow{6}{*}{$\begin{array}{l}\text { Need for Change (Adapted from Cotte and } \\
\text { Wood 2004) } \\
\text { (5-point scale, } 1=\text { disagree completely, } \\
5=\text { agree completely) } \\
\text { (Average Cronbach's alpha for self-ratings } \\
\text { is =.62; Average Cronbach's alpha for } \\
\text { rating others is =.65) }\end{array}$} & $\begin{array}{l}\text { a) When I see a new or different brand on } \\
\text { the shelf, I often pick it up just to see } \\
\text { what it is like. }\end{array}$ \\
\hline & $\begin{array}{l}\text { b) I like introducing new brands and } \\
\text { products to my friends. }\end{array}$ \\
\hline & $\begin{array}{l}\text { c) I enjoy taking chances in buying } \\
\text { unfamiliar brands just to get some variety } \\
\text { in my purchase. }\end{array}$ \\
\hline & $\begin{array}{l}\text { d) I often read the information on the } \\
\text { packages of products just out of curiosity. }\end{array}$ \\
\hline & $\begin{array}{l}\text { e) I get bored with buying the same } \\
\text { brands even if they are good. }\end{array}$ \\
\hline & $\begin{array}{l}\text { f) I shop around a lot for my clothes just } \\
\text { to find out more about the latest styles. }\end{array}$ \\
\hline
\end{tabular}

